\title{
PENGARUH DESENTRALISASI FISKAL TERHADAP TINGKAT PENGANGGURAN DI WILAYAH SUMATERA
}

Riski Prasetyo Putro

Direktorat Pelaksanaan Anggaran

Alamat Korespondensi:riskiputro@gmail.com

\section{INFORMASI ARTIKEL}

Diterima Pertama

9 Juni 2016

Dinyatakan Diterima

8 September 2016

KATA KUNCI:

Fiscal Decentralization, Government Expenditures, General Allocation Fund (DAU), Special Allocation Fund (DAK), Capital Expenditures, Unemployment Rate.

KLASIFIKASI JEL:

E24, E25, H500, H700.

\section{ABSTRAK}

Through fiscal decentralization, local governments are expected to assume more responsibility for regional problems such as unemployment. This study aims to analyze the effect of fiscal decentralization on the unemployment rate in Sumatra for the period 2006 to 2013. This quantitative research used panel data and multiple regression analyses. The results show that Regional Revenue and Revenue Sharing Fund have negative effects on the unemployment rate. Capital expenditures negatively affect the unemployment rate for the next two years, while goods and services expenditures have a positive effect on the unemployment rate. In addition, the General Allocation Fund, Special Allocation Fund and personnel expenditure do not affect the unemployment rate.

Melalui desentralisasi fiskal, pemerintah daerah diharapkan mampu menyelesaikan berbagai permasalahan daerah, antara lain pengangguran. Penelitian ini bertujuan mengetahui pengaruh pelaksanaan desentralisasi fiskal terhadap tingkat pengangguran di Wilayah Sumatera selama periode 2006 s.d. 2013. Penelitian ini merupakan penelitian kuantitatif dengan data panel dan teknik analisis regresi linier berganda. Hasil penelitian menunjukkan bahwa Pendapatan Asli Daerah dan Dana Bagi Hasil berpengaruh negatif terhadap tingkat pengangguran. Belanja modal berpengaruh negatif terhadap tingkat pengangguran pada dua tahun berikutnya, sedangkan belanja barang dan jasa justru berpengaruh positif terhadap tingkat pengangguran. Selain itu, Dana Alokasi Umum, Dana Alokasi Khusus, dan belanja pegawai tidak berpengaruh signifikan terhadap tingkat pengangguran. 


\section{PENDAHULUAN}

\subsection{Latar Belakang}

Salah satu peran pemerintah dalam pembangunan adalah meningkatkan kesejahteraan secara merata bagi seluruh masyarakat. Pemerintah menetapkan kebijakan fiskal sebagai salah satu upaya dalam meningkatkan kesejahteraan masyarakat melalui programprogram pembangunan yang akan mendorong pertumbuhan ekonomi, menurunkan tingkat pengangguran dan kemiskinan, serta meningkatkan taraf hidup rakyat miskin.

Dalam melaksanakan program-program tersebut pemerintah menghadapi beberapa tantangan, antara lain keadaan geografis dan kondisi setiap wilayah di Indonesia yang berbeda satu sama lain. Pemerintah juga menghadapi tantangan dari sisi permasalahan kependudukan. Berdasarkan hasil sensus penduduk periode tahun 2000 s.d. 2010 oleh Badan Pusat Statistik (2011), laju pertumbuhan penduduk Indonesia sebesar 1,49 persen. Angka tersebut merupakan peningkatan hasil sensus penduduk atas periode sebelumnya, yaitu tahun 1990 s.d. 2000 yang hanya mencapai 1,44 persen. Dampak dari pertumbuhan penduduk ini adalah lonjakan jumlah penduduk usia muda. Konsekuensinya, pemerintah harus memfasilitasi kebutuhan dasar penduduk seperti pendidikan, kesehatan, dan menciptakan lapangan pekerjaan yang memadai.

Pelaksanaan desentralisasi fiskal melalui penyerahan wewenang pemerintahan dari pemerintah pusat kepada pemerintah daerah untuk mengatur berbagai urusan pemerintahan diharapkan dapat memberikan manfaat dalam pemerataan pembangunan. Selain diberi kewenangan untuk menggali sumber keuangan sendiri berupa Pendapatan Asli Daerah (PAD), pemerintah daerah juga memperoleh dana perimbangan berupa Dana Alokasi Umum (DAU), Dana Alokasi Khusus (DAK), dan Dana Bagi Hasil (DBH).

Dengan adanya otonomi daerah, pemerintah daerah diharapkan mampu menyelesaikan permasalahan yang belum tuntas diantaranya adalah masalah pengangguran. Menurut Keynes dalam Sukirno, pemerintah perlu campur tangan dalam mengatasi pengangguran melalui belanja pemerintah yang akan meningkatkan permintaan agregat. $^{1}$ Kenaikan permintaan agregat akan meningkatkan kesempatan kerja dan mengurangi pengangguran.

Berbagai penelitian dilakukan untuk mengetahui pengaruh peranan pemerintah

1 Sadono Sukirno, Makroekonomi Modern, (Jakarta: PT. Raja Grafindo, 2000), hlm. 251. terhadap pengangguran. Penelitian yang dilakukan oleh Alanis dan Mahdavi menunjukkan bahwa pengeluaran pemerintah dalam bentuk belanja pegawai, belanja bantuan dan subsidi memiliki pengaruh negatif terhadap tingkat pengangguran, sedangkan belanja modal dan asuransi sosial tidak berpengaruh signifikan. ${ }^{2}$ Penelitian oleh Murwirapachena, et al. membuktikan bahwa pengeluaran pemerintah untuk infrastruktur berpengaruh negatif terhadap tingkat pengangguran, sedangkan pajak dan pengeluaran konsumsi barang dan jasa pemerintah berpengaruh positif terhadap tingkat pengangguran. ${ }^{3}$ Sejalan dengan penelitian tersebut, Akhmad, et al. menyimpulkan bahwa dengan meningkatkan belanja modal dan mengurangi belanja barang dan jasa, pengangguran dapat berkurang, namun kenaikan PAD berpengaruh positif terhadap pengangguran. ${ }^{4}$ Penelitian lain oleh Muda, et al. membuktikan bahwa PAD, DAU, DAK, DBH, dan Opini Badan Pemeriksa Keuangan (BPK) berpengaruh negatif dan signifikan terhadap pengangguran. ${ }^{5}$ Hasil penelitian-penelitian tersebut merupakan bahan pertimbangan bagi pemerintah dalam mengevaluasi efektifitas kebijakan fiskal dalam menurunkan angka pengangguran.

Berdasarkan data World Bank, pada tahun 2013 Indonesia berada di peringkat kedua dengan tingkat pengangguran tertinggi di antara negaranegara ASEAN. Sementara itu, berdasarkan hasil survei BPS (2013), Aceh tercatat sebagai provinsi dengan tingkat pengangguran tertinggi, yaitu sebesar $10,3 \%$ dan rata-rata tingkat pengangguran provinsi di wilayah Sumatera sebesar 6\%, lebih

2 Saeid Mahdavi dan Emmanuel Alanis, "Public Expenditures and The Unemployment Rate in American States: Panel Evidence". Applied Economics, 2013, Vol. 45, hlm. 2926-2937.

3 Genius Murwirapachena, et al.,"Fiscal Policy and Unemployment in South Africa: From 1980 to 2010". Mediterranean Journal of Social Sciences, 2013, Vol. 4, hlm. 579-587.

4 Akhmad, et al. "The Impact of Fiscal Policy on the Regional Economy: Evidence from South Sulawesi, Indonesia". Journal of Applied Sciences Research, 2013, Vol. 45, hlm. 2463-2474.

5 Iskandar Muda, et al.,"The Effect of Fiscal Potential, Fiscal Needs and Internal Control on the Provincial Intergovernmental Transfer Allocation in the Districts/ Cities in North Sumatera, Indonesia". International Journal of Management Sciences and Business Research, 2014, Vol. 3, hlm. 22-35. 
tinggi daripada rata-rata tingkat pengangguran nasional sebesar 5,4\%.

\section{Grafik 1. Tingkat Pengangguran Negara Anggota} ASEAN

(dalam persen)

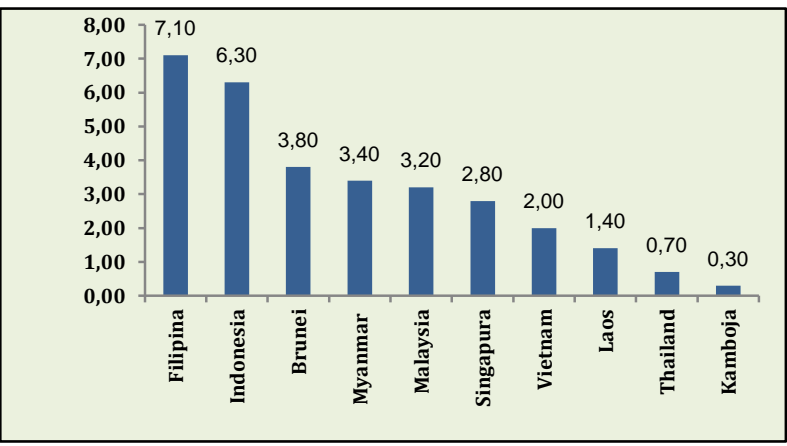

Sumber: World Bank (2013)

Dengan memanfaatkan dana perimbangan yang secara rutin diterima dan adanya kewenangan untuk menggali sumber-sumber keuangan sendiri, pemerintah daerah di Wilayah Sumatera diharapkan mampu menjalankan fungsi alokasi Anggaran Pendapatan dan Belanja Daerah (APBD) secara optimal. APBD diarahkan untuk peningkatan kesejahteraan masyarakat, antara lain untuk mengurangi pengangguran, sebagaimana yang telah dinyatakan pada penjelasan Pasal 66 Ayat (3) Undang-Undang No. 33 Tahun 2004 tentang Perimbangan Keuangan antara Pemerintah Pusat dan Pemerintahan Daerah.

\section{KERANGKA TEORI DAN PENGEM- BANGAN HIPOTESIS}

\subsection{Ketenagakerjaan dan Pengangguran}

Salah satu permasalahan ketenagakerjaan adalah ketidakseimbangan antara permintaan tenaga kerja dan penawaran tenaga kerja. Penawaran tenaga kerja yang lebih besar daripada permintaan tenaga kerja akan menimbulkan pengangguran. Lewis menyebutkan bahwa pada umumnya negara-negara berkembang mengalami permasalahan pengangguran. ${ }^{6}$ Hal-hal yang mengakibatkan tingginya pengangguran adalah tingkat kelahiran yang tinggi, banyaknya pekerja harian, pedagang kecil dan petani-petani kecil. Negara-negara yang mempunyai kelebihan tenaga kerja ini berpenduduk besar dan produktivitas marjinalnya sangat rendah, bahkan nol atau negatif.

Teori Lewis ini didukung oleh Ranis dan Fei yang menyatakan bahwa di negara-negara berkembang terdapat jumlah buruh yang berlebih, banyaknya pengangguran, dan sumber daya alam

6 W. Arthur Lewis, "Economic Development with Unlimited Surplus of Labour". The Manchester School, 1954, Vol. 22, hlm. 139-191. yang belum dapat diolah dengan baik. ${ }^{7}$ Pada umumnya, laju pertumbuhan tenaga kerja pada negara berkembang lebih cepat daripada laju pertumbuhan lapangan kerja. Untuk itu, negaranegara berkembang harus meningkatkan upaya dalam mengurangi pengangguran.

Sukirno mendefinisikan pengangguran sebagai seseorang yang sedang mencari pekerjaan pada suatu tingkat upah tertentu, namun tidak dapat memperoleh pekerjaan sesuai dengan yang diinginkan. ${ }^{8}$ Seseorang dianggap menganggur jika sedang mencari pekerjaan, sedang mempersiapkan usaha dan tidak bekerja, mendapat pekerjaan tetapi belum mulai bekerja, serta yang tidak mungkin mendapatkan pekerjaan. Tingkat pengangguran dihitung dengan membandingkan antara jumlah penduduk yang menganggur dengan jumlah angkatan kerja. Badan Pusat Statistik (2013) menyatakan bahwa angkatan kerja merupakan jumlah penduduk usia kerja yang bekerja dan menganggur.

\subsection{Peranan Pemerintah}

Secara teoritis, permasalahan pengangguran pada awalnya diangkat oleh Adam Smith, ahli ekonomi aliran klasik yang tidak menyetujui campur tangan pemerintah yang aktif untuk mengatur kegiatan perekonomian. Saat pengangguran meningkat, ahli ekonomi klasik berpendapat bahwa peran pemerintah tidak diperlukan karena melalui mekanisme pasar bebas masalah pengangguran akan teratasi dan kesempatan kerja penuh pada akhirnya dapat tercapai kembali.

Berbeda dengan pandangan aliran klasik yang dipelopori oleh Adam Smith tersebut, John Maynard Keynes sebagaimana disebutkan dalam Sukirno, menganggap bahwa pemerintah memiliki peranan dalam mengurangi pengangguran karena kesempatan kerja penuh pada sistem pasar bebas jarang tercapai. ${ }^{9}$ Hal ini dikarenakan adanya kekurangan permintaan agregat sehingga penawaran agregat menurun. Oleh karena itu, kebijakan fiskal pemerintah sangat penting untuk mengatasi masalah pengangguran. Pemerintah dapat meningkatkan belanja agar permintaan agregat dapat meningkat. Perubahan keseimbangan antara permintaan agregat dan penawaran agregat dapat ditunjukkan sebagaimana pada Grafik 2.

7 Gustav Ranis dan John C. H. Fei, "A Theory of Economic Development". The American Economic Review, 1961, Vol. 51, hlm. 533-565.

8 Sadono Sukirno, Op.Cit., hlm. 472.

9 Ibid., hlm. 251. 


\section{Grafik 2. Keseimbangan AD-AS dalam Analisis} Keynes

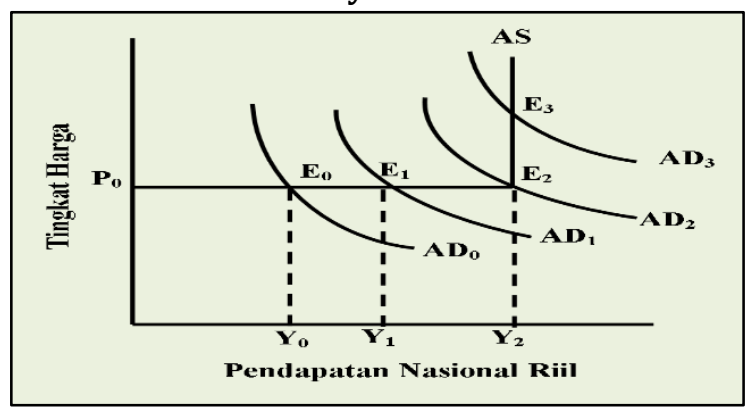

Sumber: Sukirno, Sadono (2000)

Keseimbangan antara permintaan dan penawaran agregat pada awalnya tercapai di titik $\mathrm{E}_{0}$ yang disebabkan permintaan agregat yang relatif rendah, yaitu sebanyak $A_{0}$. Pada titik tersebut, pendapatan nasional hanya $\mathrm{Y}_{0}$ dan berada dibawah pendapatan nasional pada kesempatan kerja penuh yaitu $\mathrm{Y}_{2}$. Adanya jurang antara $\mathrm{Y}_{2}$ dengan $\mathrm{Y}_{0}$ inilah yang menimbulkan pengangguran.

Dengan meningkatkan belanja, pemerintah mampu menaikkan keseimbangan yang terbentuk oleh permintaan dan penawaran agregat. Keseimbangan bergeser ke titik $\mathrm{E}_{1}$ dan pendapatan nasional meningkat menjadi $Y_{1}$. Perubahan ini akan menambah kesempatan kerja bagi angkatan kerja dan mengurangi pengangguran.

Namun, pada tahun 1970-an para ekonom mulai mempertanyakan pemikiran Keynes. Hal ini disebabkan teori Keynes tidak mampu mengatasi permasalahan stagflasi yang terjadi pada saat itu. Stagflasi merupakan keadaan di mana pertumbuhan ekonomi melambat, inflasi tinggi dan diikuti dengan tingkat pengangguran yang juga tinggi. Pada saat terjadi stagflasi, keseimbangan ekonomi tidak ditentukan oleh permintaan agregat melainkan oleh penawaran agregat. Hal ini berbeda dengan analisis Keynes yang menyatakan bahwa permintaan agregat mempengaruhi penawaran agregat dan menentukan titik keseimbangan ekonomi.

Atas permasalahan tersebut, muncul pemikiran baru yang disebut kelompok Keynesian Baru yang dipelopori oleh beberapa ekonom, antara lain David Romer, Stanley Fisher, Bruce Greenwald, Paul Krugman, dan Nicholas Gregory Mankiw. Golongan Keynesian Baru menambahkan hal-hal yang belum diangkat dalam teori Keynes sebelumnya, yaitu terkait sikap pelaku kegiatan ekonomi yang akan selalu melakukan aktivitas perekonomian yang mereka jalankan secara rasional dengan selalu berusaha untuk memaksimumkan kepuasan dan keuntungan masing-masing. Selain itu, golongan Keynesian Baru juga menyesuaikan pasaran tenaga kerja dalam makroekonomi dengan bentuk pasaran tenaga kerja dalam mikroekonomi.
Golongan Keynesian Baru masih berpegang pada beberapa prinsip teori yang dinyatakan oleh Keynes. Mereka meyakini bahwa sistem pasar bebas tidak akan mampu mengurangi pengangguran dengan sendirinya dalam jangka panjang. Mereka juga menyimpulkan bahwa kebijakan fiskal pemerintah yang bersifat menstimulus permintaan agregat dapat bermanfaat dalam mewujudkan pertumbuhan ekonomi yang tinggi dan stabil.

\subsection{Desentralisasi Fiskal}

Dalam tulisannya yang berjudul "A Pure Theory of Local Expenditures", Charles M. Tiebout menyatakan bahwa setiap daerah harus mengatur pendapatan dan belanja daerah sesuai dengan kebutuhan penduduknya. Hal ini mendukung konsep desentralisasi fiskal, di mana kewenangan untuk mengelola anggaran berada di tangan pemerintah daerah. ${ }^{10}$

Pemerintah daerah sebagai unit pemerintahan terdekat dengan rakyat diberi keleluasaan untuk mengalokasikan pengeluarannya dalam melayani kebutuhan rakyat. Pemerintah daerah dianggap lebih mengetahui kebutuhan dan karakter masyarakat lokal sehingga program-program dari kebijakan pemerintah akan lebih efektif dan penganggaran publik akan lebih efisien. ${ }^{11}$ Selain itu, desentralisasi fiskal juga memudahkan proses pengambilan keputusan tanpa harus melewati sistem birokrasi yang panjang sehingga keputusan dapat segera diambil.

Pelaksanaan desentralisasi fiskal oleh berbagai negara di dunia ditujukan agar setiap warga negara dapat memperoleh pelayanan publik yang lebih baik dan merata. Sebagian besar negaranegara berkembang di dunia telah mengimplementasikan kebijakan desentralisasi fiskal, dan Indonesia merupakan salah satunya. Implementasi kebijakan desentralisasi fiskal di Indonesia ditandai dengan dikeluarkannya UU No. 22 Tahun 1999 tentang Pemerintahan Daerah dan UU No. 25 Tahun 1999 tentang Perimbangan Keuangan antara Pemerintah Pusat dan Daerah. ${ }^{12}$

10 Charles M. Tiebout, "A Pure Theory of Local Expenditures". Journal of Political Economy, 1956, Vol. 64, hlm. 416-424.

11 Hadi Sumarsono dan Sugeng $H$. Utomo,"Deliberate Inflation pada Kebijakan Desentralisasi Fiskal Jawa Timur dan Dampak Bagi Pertumbuhan Daerah", Jurnal Ekonomi Studi Pembangunan, 2009, Vol. 3, hlm. 157-168.

12 BKF dan World Bank, Decentralization Support Facility: Analisis Hubungan Dana Perimbangan dengan Kinerja Pelayanan Dasar Publik di Indonesia, Jakarta: BKF dan World Bank, 2011, hlm. 3 . 
Desentralisasi fiskal merupakan kebijakan pemerintah yang bertujuan untuk mengurangi kesenjangan antar daerah. Melalui desentralisasi fiskal, pemerintah daerah dapat melaksanakan urusan pemerintahan sesuai dengan kebutuhan dan karakteristik daerahnya masing-masing sehingga pelayanan publik yang diberikan dapat berjalan secara efektif dan efisien. Pemerintah daerah juga diharapkan mengutamakan pengeluaran untuk belanja pembangunan seperti perbaikan infrastruktur, pelayanan publik, pendidikan, dan kesehatan.

Pelayanan publik yang lebih baik akan mampu menarik minat masyarakat untuk berpartisipasi dalam pembangunan. Infrastruktur dan pelayanan publik yang baik akan meningkatkan efisiensi, efektivitas, dan produktivitas ekonomi. Para investor juga akan termotivasi untuk meningkatkan investasi di daerah, sehingga kesempatan kerja dapat meningkat dan tingkat pengangguran dapat berkurang.

\subsection{Perimbangan Keuangan Pusat dan Daerah}

Perbedaan kemampuan keuangan antara pemerintah pusat dan daerah dapat menyebabkan berbagai permasalahan antara lain adanya vertical fiscal imbalance dan horizontal fiscal imbalance..$^{13}$ Fiscal imbalance atau ketidakseimbangan fiskal adalah fenomena yang muncul ketika terjadi ketidakseimbangan keuangan antara pemerintah pusat dan pemerintah daerah. Ketidakseimbangan fiskal vertikal terjadi karena adanya ketidakseimbangan antara pendapatan dari tingkat pemerintahan yang lebih tinggi, yaitu pemerintah pusat, dengan pemerintahan yang lebih rendah, yaitu pemerintah daerah. Sedangkan ketidakseimbangan fiskal horizontal terjadi karena ada perbedaan kemampuan antar pemerintah daerah dalam menyediakan layanan yang disebabkan perbedaan kemampuan dalam mengumpulkan dana. Untuk mengatasi ketidakseimbangan tersebut, pemerintah pusat melakukan penyaluran dana transfer kepada pemerintah daerah agar terjadi pemerataan ekonomi.

Pendapatan pemerintah pusat yang dihimpun dari berbagai sumber penerimaan akan disalurkan kembali untuk kepentingan daerah dalam membiayai pengeluaran-pengeluaran untuk penyelenggaraan pelayanan publik. Penggunaan penerimaan pemerintah daerah tersebut tidak boleh dialokasikan untuk satu sektor atau daerah tertentu, tetapi merata ke seluruh sektor dan

13 Budi Mulyana, et al., Keuangan Daerah: Perspektif Desentralisasi Fiskal dan Pengelolaan APBD di Indonesia, Jakarta: LPKPAP, 2006, hlm. 69. seluruh daerah di Indonesia. Oleh karena itu, dengan adanya desentralisasi fiskal yang didukung dengan penyaluran dana transfer tersebut, percepatan pembangunan diharapkan dapat tercapai.

UU No. 17 Tahun 2003 tentang Keuangan Negara menegaskan bahwa pemerintah pusat memiliki kewajiban untuk menyalurkan dana perimbangan kepada pemerintah daerah secara rutin. Dana perimbangan terdiri dari Dana Alokasi Umum (DAU), Dana Alokasi Khusus (DAK), dan Dana Bagi Hasil (DBH.) Penyaluran DAU dan DBH bersifat unconditional grant atau block grant di mana pemerintah pusat tidak mensyaratkan pemerintah daerah dalam penggunaan anggaran sehingga bisa dialokasikan sesuai dengan kebutuhan daerah. Berbeda dengan DAU dan DBH, penyaluran DAK bersifat specific grant karena penyalurannya ditujukan secara khusus untuk mendanai kebutuhan sarana dan prasarana dasar yang merupakan prioritas nasional.

Sumber pendapatan pemerintah daerah berupa PAD, DAU, DAK, dan DBH akan memberi peluang bagi pemerintah daerah untuk meningkatkan penyelenggaraan pemerintahan secara optimal. Namun, pelaksanaan desentralisasi fiskal yang baik tidak hanya terbatas pada sistem penerimaan pemerintah daerah saja, tetapi juga menyangkut efisiensi dalam pengalokasian pendapatan pemerintah daerah tersebut untuk membiayai pengeluaran pemerintah daerah. Pengeluaran pemerintah daerah perlu diarahkan untuk kegiatan-kegiatan yang bersifat produktif dan memberikan manfaat bagi masyarakat di daerah.

Jika setiap daerah mampu meningkatkan kualitas sistem penerimaan, mengalokasikan pengeluaran dengan efektif dan efisien, serta mengoptimalkan dan mengelola anggarannya dengan baik, pembangunan di daerah dapat meningkat dan kondisi perekonomian yang stabil dan pertumbuhan ekonomi akan tercapai. Hal ini akan mendorong kenaikan permintaan agregat yang diikuti dengan kenaikan penawaran agregat, sehingga ada peningkatan kebutuhan tenaga kerja. Dengan kata lain, lapangan kerja bagi penduduk akan tercipta dan tingkat pengangguran dapat mengalami penurunan.

\subsection{Penelitian Terdahulu}

Penelitian ini mengacu pada beberapa penelitian sebelumnya yang terkait dengan pengaruh kebijakan fiskal pemerintah terhadap tingkat pengangguran. Beberapa penelitian tersebut antara lain:

1. Penelitian Mahdavi dan Alanis (2013) dengan judul Public Expenditures and The Unemployment Rate in American States: Panel 
Evidence. Penelitian tersebut meneliti 50 negara bagian di Amerika Serikat pada periode 1977 s.d. 2006. ${ }^{14}$ Hasil penelitian menyebutkan bahwa pengeluaran pemerintah atas belanja pegawai, belanja bantuan dan subsidi mampu menurunkan tingkat pengangguran secara signifikan. Sementara itu, belanja modal dan asuransi sosial tidak berpengaruh signifikan terhadap tingkat pengangguran.

2. Penelitian Murwirapachena, et al. (2013) dengan judul Fiscal Policy and Unemployment in South Africa: from 1980 to 2010. Penelitian tersebut membahas kebijakan fiskal di Afrika Selatan sepanjang tahun 1980 s.d. $2010 .{ }^{15}$ Hasil penelitian menunjukkan bahwa pajak, pengeluaran konsumsi barang dan jasa pemerintah berdampak positif dan signifikan terhadap pengangguran. Sementara itu, pengeluaran untuk infrastruktur berpengaruh negatif dan signifikan terhadap pengangguran. Penelitian ini juga memberikan rekomendasi kepada pemerintah agar mengurangi tarif pajak penghasilan badan dari 28\% menjadi kurang dari $20 \%$ seperti yang diadopsi oleh negara anggota Organization for Economic Cooperation and Development (OECD) lainnya antara lain Islandia, Turki, Polandia dan Irlandia. Pemerintah juga diharapkan dapat meniru tarif pajak penghasilan pribadi yang relatif rendah seperti yang diadopsi oleh negara-negara berkembang lainnya seperti Meksiko, India, Brasil, Botswana dan Mesir. Selain itu, pemerintah perlu meningkatkan pengeluaran untuk pembangunan infrastruktur dan mengurangi konsumsi barang dan jasa pemerintah untuk mengurangi tingginya angka pengangguran.

3. Penelitian Akhmad, et al. (2013) dengan judul The Impact of Fiscal Policy on the Regional Economy: Evidence from South Sulawesi, Indonesia. Penelitian tersebut meneliti kebijakan desentralisasi fiskal di Sulawesi Selatan. ${ }^{16}$ Penelitian menggunakan data pendapatan dan belanja daerah 23 kabupaten/ kota periode 20042009. Hasil penelitian menyebutkan bahwa peningkatan PAD meningkatkan pengangguran. Sementara itu, kenaikan belanja pemerintah dalam rangka peningkatan belanja modal, baik untuk pembangunan infrastruktur di sektor pertanian maupun nonpertanian dan penurunan atas alokasi belanja barang dan jasa, lebih efektif dalam meningkatkan pertumbuhan ekonomi, mengurangi pengangguran dan kemiskinan.

4. Penelitian Muda, et al. (2014) dengan judul The effect of Fiscal Potential, Fiscal Needs and

14 Saeid Mahdavi dan Emmanuel Alanis, Loc.Cit., hlm. 2926-2937.

15

Murwirapachena, Loc.Cit., hlm. 579-587.

16 Akhmad, et al., Loc.Cit., hlm. 2463-2474.
Internal Control on The Provincial Intergovernmental Transfer Allocation in The Districts/Cities in North Sumatera, Indonesia. Penelitian tersebut bertujuan untuk melihat pengaruh kebijakan fiskal pemerintah berupa penyaluran dana perimbangan pada Provinsi Sumatera Utara terhadap pencapaian kinerja keuangan dan ekonomi. Data penelitian mencakup 25 kabupaten/ kota di Provinsi Sumatera Utara periode 2005-2012. Hasil penelitian menunjukkan bahwa PAD, DAU, DAK, DBH dan Opini BPK memiliki pengaruh yang negatif dan signifikan terhadap pengangguran di Provinsi Sumatera Utara. ${ }^{17}$

\subsection{Kerangka Pikir}

Kerangka pemikiran yang menjadi gambaran umum hubungan antarvariabel dalam penelitian ini adalah sebagai berikut:

Gambar 1. Kerangka Pemikiran Penelitian

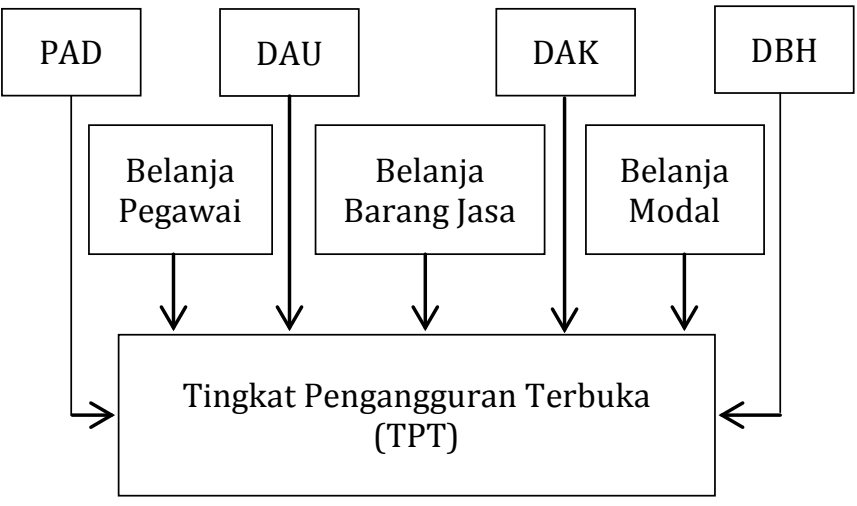

Pelaksanaan desentralisasi fiskal direpresentasikan dengan adanya penerimaan pemerintah daerah berupa PAD dan dana perimbangan, serta kewenangan pengalokasian belanja daerah. Sementara itu, permasalahan pengangguran direpresentasikan dengan tingkat pengangguran terbuka. Dengan menggunakan kerangka pemikiran di atas, diharapkan pengaruh dari pelaksanaan desentralisasi fiskal terhadap tingkat pengangguran dapat diketahui.

\subsection{Hipotesis} berikut:

Hipotesis pada penelitian ini adalah sebagai

1. Kemandirian fiskal daerah dalam menggali potensi sumber keuangan diduga dapat menurunkan tingkat pengangguran. Untuk mengetahui pengaruh tersebut, hipotesis yang dirumuskan adalah:

$\mathrm{H}_{\mathrm{a} 1}$ : PAD berpengaruh negatif dan signifikan terhadap TPT.

17 Muda, et al., Loc.Cit., hlm. 22-35 
2. Dana perimbangan diduga mampu menurunkan tingkat pengangguran. Untuk mengetahui pengaruh tersebut, hipotesis yang dirumuskan adalah:

$\mathrm{H}_{\mathrm{a} 2}$ : DAU berpengaruh negatif dan signifikan terhadap TPT.

$\mathrm{H}_{\mathrm{a} 3}$ : DAK berpengaruh negatif dan signifikan terhadap TPT.

$\mathrm{H}_{\mathrm{a} 4}$ : DBH berpengaruh negatif dan signifikan terhadap TPT.

3. Alokasi belanja daerah diduga mampu menurunkan tingkat pengangguran. Untuk mengetahui pengaruh tersebut, hipotesis yang dirumuskan adalah:

$\mathrm{H}_{\mathrm{a} 5}$ : Belanja pegawai berpengaruh negatif dan signifikan terhadap TPT.

$\mathrm{H}_{\mathrm{a} 6}$ : Belanja barang dan jasa berpengaruh negatif dan signifikan terhadap TPT.

$\mathrm{H}_{\mathrm{a}}$ : Belanja modal berpengaruh negatif dan signifikan terhadap TPT.

\section{METODOLOGI PENELITIAN}

\subsection{Metode Penelitian}

Jenis penelitian yang digunakan dalam penelitian ini adalah kuantitatif. Data-data yang diperoleh dan dikumpulkan akan dianalisis dan diolah. Selanjutnya akan dilakukan interpretasi dan pembahasan yang mengacu pada hasil analisis tersebut.

\subsection{Pendekatan Penelitian}

Data yang digunakan merupakan data sekunder berupa data kuantitatif yang terdiri dari: data keuangan atas realisasi APBD dan data tingkat pengangguran terbuka. Data realisasi APBD mencakup data: PAD, DAU, DAK, DBH, belanja pegawai, belanja barang dan jasa, dan belanja modal. Penelitian mencakup 10 (sepuluh) provinsi yang berada di Wilayah Sumatera pada periode 2006-2013. Data diperoleh dari Badan Pusat Statistik (BPS).

\subsection{Definisi Operasional dan Cara Pengukuran Variabel}

Variabel dalam penelitian ini adalah tingkat pengangguran terbuka sebagai variabel terikat, sedangkan variabel bebas mencakup: PAD, DAU, DAK, DBH, belanja pegawai, belanja barang dan jasa, serta belanja modal. Untuk menghindari bias, maka penulis melakukan standardisasi nilai atas variabel-variabel yang digunakan sehingga nilainya tidak berbeda jauh antara satu variabel dengan variabel lainnya. Satuan untuk nilai variabel bebas adalah ratusan miliar Rupiah, sedangkan untuk nilai variabel terikat adalah dalam bentuk persentase. Definisi dari masing-masing variabel adalah sebagai berikut:
1. Pendapatan Asli Daerah (PAD) adalah pendapatan pemerintah daerah atas pungutan yang dilaksanakan atas dasar peraturan daerah dan peraturan perundang-undangan yang berlaku. Variabel PAD diukur dari penjumlahan atas pajak daerah, retribusi daerah, hasil pengelolaan kekayaan daerah yang dipisahkan, dan lain-lain PAD.

2. Dana Alokasi Umum (DAU) adalah dana yang berasal dari pendapatan APBN untuk meningkatkan pemerataan kemampuan keuangan antardaerah untuk mendanai kebutuhan daerah dalam rangka pelaksanaan desentralisasi. Variabel DAU diukur dari realisasi DAU yang disalurkan oleh pemerintah pusat kepada pemerintah daerah.

3. Dana Alokasi Khusus (DAK) adalah dana yang berasal dari pendapatan APBN dan disalurkan untuk mendanai kegiatan khusus sesuai dengan prioritas nasional yang ditetapkan oleh pemerintah pusat. Variabel DAK diukur dari realisasi DAK yang disalurkan oleh pemerintah pusat.

4. Dana Bagi Hasil (DBH) adalah dana yang berasal dari APBN untuk mendanai kebutuhan daerah khususnya dalam rangka pelaksanaan desentralisasi dan dialokasikan sesuai dengan angka persentase yang telah ditetapkan. Variabel DBH diukur dari realisasi DBH yang disalurkan oleh pemerintah pusat.

5. Belanja pegawai adalah kompensasi bagi pegawai pemerintah sebagai imbalan pekerjaan, kecuali kegiatan yang mempunyai output atas belanja barang atau belanja modal. Variabel belanja pegawai diukur dari realisasi belanja pegawai yang dikeluarkan.

6. Belanja barang dan jasa adalah pengeluaran atas penyediaan barang dan jasa yang manfaatnya kurang dari satu tahun. Variabel belanja barang dan jasa diukur dari realisasi belanja barang dan jasa yang dikeluarkan.

7. Belanja modal adalah pengeluaran yang sifatnya menambah, mempertahankan, atau meningkatkan kualitas aset dengan manfaat lebih dari satu periode akuntansi. Variabel belanja modal diukur dari realisasi belanja modal yang dikeluarkan oleh pemerintah daerah dua tahun sebelumnya.

8. Tingkat Pengangguran Terbuka (TPT) adalah perbandingan jumlah pencari kerja dengan jumlah angkatan kerja. Variabel tingkat pengangguran terbuka diukur dari persentase atas jumlah pengangguran terhadap angkatan kerja. 


\subsection{Metode Pengumpulan Data}

Metode pengumpulan data yang dilakukan dalam penelitian ini adalah metode dokumentasi yaitu dengan mengumpulkan, mencatat, dan mengolah data yang berkaitan dengan penelitian.

\subsection{Metode Analisis Regresi Linier Berganda}

Penelitian ini menggunakan analisis regresi linier berganda dengan data panel. Dengan menggunakan data panel, variasi antar individu yang berbeda dan dalam kurun waktu tertentu dapat diperoleh. Untuk mengestimasi parameter model data panel, terdapat beberapa model yang ditawarkan, yaitu:

\section{Model common effect}

Model common effect mengkombinasikan data time series dan data cross section dalam bentuk pool. Model ini tidak memperhitungkan adanya perbedaan individu dan waktu, sehingga perilaku setiap individu dianggap sama dalam berbagai kurun waktu.

\section{Model fixed effect}

Model ini memperhatikan keragaman atau heterogenitas individu yakni dengan mengasumsikan bahwa intercept antar kelompok individu berbeda, sedangkan slope dianggap sama. Model ini mengasumsikan bahwa perbedaan antar individu dapat diakomodasi melalui perbedaan intercept tersebut.

\section{Model random effect}

Berbeda dengan model fixed effect yang perbedaan antara individu dan/atau waktunya dicerminkan melalui intercept, perbedaan antara individu dan/atau waktu pada model random effect dicerminkan melalui error.

Persamaan regresi dari penelitian ini adalah sebagai berikut:

$$
\begin{aligned}
T P T_{i t}= & \propto+\beta_{1} P A D_{i t}+\beta_{1} P A D_{i t}+\beta_{2} D A U_{i t}+ \\
& \beta_{3} D A K_{i t}+\beta_{4} D B H_{i t}+\beta_{5} B P G_{i t}+ \\
& \beta_{6} B B J_{i t}+\beta_{7} B M D_{i t-2}+\varepsilon_{i t}
\end{aligned}
$$

Keterangan:

$$
\begin{array}{ll}
\alpha & =\text { konstanta } \\
\beta & =\text { koefisien } \\
\varepsilon & =\text { error term } \\
P A D & =\text { Pendapatan Asli Daerah } \\
D A U & =\text { Dana Alokasi Umum } \\
D A K & =\text { Dana Alokasi Khusus } \\
D B H & =\text { Dana Bagi Hasil } \\
B P G & =\text { Belanja Pegawai } \\
B B J & =\text { Belanja Barang dan Jasa } \\
B M D & =\text { Belanja Modal } \\
T P T & =\text { Tingkat Pengangguran }
\end{array}
$$

\subsection{Uji Asumsi Klasik}

Uji asumsi klasik yang dilakukan dalam penelitian ini meliputi:

a. Uji normalitas

Uji normalitas merupakan uji asumsi klasik yang perlu dilakukan dalam analisis regresi berganda. Jika data yang digunakan telah berdistribusi secara normal, uji signifikansi pengaruh variabel bebas terhadap variabel terikat menjadi valid. Data yang terdistribusi normal dapat diketahui dengan membandingkan nilai probabilitas dari JarqueBera dengan tingkat signifikansi yang digunakan dalam penelitian. Hipotesis yang digunakan adalah:

\section{$\mathrm{H}_{0}$ : Data berdistribusi normal \\ $\mathrm{H}_{1}$ : Data tidak berdistribusi normal}

Jika hasil probabilitas Jarque-Bera lebih besar dari 5\%, hipotesis nol ditolak, artinya data berdistribusi normal. Jika hasil probabilitas Jarque-Bera lebih kecil dari 5\%, hipotesis nol dapat disimpulkan bahwa data tidak berdistribusi normal.

b. Uji multikolinieritas

Uji multikolinieritas diperlukan untuk mengetahui apakah variabel bebas memiliki kemiripan dengan variabel bebas lain. ${ }^{18} \mathrm{Uji}$ multikoliniearitas bertujuan untuk menghindari bias dalam proses pengambilan keputusan mengenai pengaruh pada uji parsial atau uji $t$ setiap variabel bebas terhadap variabel terikat. Untuk melakukan uji multikolinieritas, peneliti dapat mengamati matriks korelasi dari variabel bebas, jika terdapat koefisien korelasi lebih dari 0,80 maka terdapat multikolinieritas. ${ }^{19}$

\section{c. Uji autokorelasi}

Uji autokorelasi menguji hubungan residual satu observasi dengan residual observasi lainnya, atau hubungan antara residual satu observasi pada periode tertentu dengan periode sebelumnya. Salah satu cara untuk mendeteksi autokorelasi adalah dengan metode Durbin-Watson dan melihat nilai $d U$ dan $d L$ melalui tabel Durbin-Watson untuk menentukan apakah terdapat autokorelasi atau tidak. Apabila nilai Durbin-Watson berada di

18 Bhuono Agung Nugroho, Strategi Jitu Memilih Metode Statistik Penelitian Dengan SPSS, (Yogyakarta: ANDI, 2005).

19 Damodar Gujarati, Basic Econometrics. Edisi ke4. (New York: The McGraw-Hill Companies, 2006). 
antara $d U$ dan $4-d U$ maka dapat disimpulkan bahwa tidak terdapat autokorelasi.

d. Uji heteroskedastisitas

Agar hasil estimasi regresi baik dan tidak bias, model regresi harus bersifat homoskesdastis, yaitu memiliki kesamaan variance residual suatu periode pengamatan dengan pengamatan lain. $^{20}$ Oleh karena itu dilakukan uji heteroskedastisitas untuk menguji apakah terjadi heteroskedastisitas, yang ditandai dengan adanya ketidaksamaan variance residual.

Ada beberapa cara untuk mendeteksi ada/ tidaknya heterokedastisitas, salah satunya adalah dengan uji Glejser (Gujarati, 2006). Uji Glejser dilakukan dengan meregresikan nilai absolut residual terhadap variabel bebas, dan jika terdapat variabel bebas yang secara signifikan mempengaruhi nilai absolut residual tersebut, maka dapat disimpulkan bahwa terdapat situasi heteroskedastisitas dalam model penelitian.

\section{e. Uji Koefisien Determinasi}

Koefisien determinasi bertujuan untuk menguji tingkat keeratan atau keterikatan antarvariabel terikat dan variabel bebas yang bisa dilihat dari besarnya nilai koefisien determinasi ( $R$-square). Nilai koefisien determinasi bernilai antara nol dan satu, dengan nol sebagai nilai terendah dan satu sebagai nilai tertinggi. Nilai $R$-square yang rendah menandakan bahwa variabel-variabel bebas belum mampu menjelaskan variabel terikat. Nilai koefisien determinasi yang tinggi menandakan bahwa variabel-variabel bebas telah memberikan informasi yang dibutuhkan untuk memprediksi variabel terikat (Ghozali, 2005).

\section{f. Uji Hipotesis}

Uji hipotesis dilakukan melalui Uji t. Uji $t$ dilakukan untuk mengetahui apakah masingmasing variabel bebas mempengaruhi variabel terikat secara signifikan. Pengujian parsial dilakukan dengan uji $t$. Cara melakukan uji $\mathrm{t}$ adalah dengan membandingkan t-hitung dengan $t$-tabel pada tingkat signifikansi $5 \%$, serta membandingkan probabilitas dari t-hitung dengan tingkat signifikansi. Pengujian ini menggunakan kriteria:

$\mathrm{H}_{0}$ : tidak ada pengaruh signifikan antara variabel bebas terhadap variabel terikat.

20 Imam Ghozali, Aplikasi Analisis Multivariate dengan Program SPSS, (Semarang: Badan Penerbit Universitas Diponegoro, 2005).
$\mathrm{H}_{\mathrm{a}}$ : ada pengaruh signifikan antara variabel bebas terhadap variabel terikat.

Jika t-hitung bernilai negatif, maka digunakan nilai absolut dari t-hitung tersebut (Gujarati, 2005). Hipotesis nol ditolak jika nilai absolut $t$ hitung lebih besar daripada nilai $t$-tabel. Selain itu, uji $t$ juga dilakukan terhadap probabilitas $t$ hitung atas variabel bebas. Jika nilai probabilitas t-hitung lebih kecil dari 5\% maka $\mathrm{H}_{0}$ ditolak, artinya variabel bebas mempunyai pengaruh yang signifikan terhadap variabel terikat.

\subsection{Sarana yang Digunakan}

Untuk keperluan pengolahan dan analisis data dalam rangka pengujian hipotesis, penelitian ini menggunakan program aplikasi Eviews versi 7.2. Program aplikasi Eviews versi 7.2 digunakan dalam proses entry data, analisis statistik deskriptif, uji asumsi klasik, estimasi regresi linier berganda, dan pengujian hipotesis.

\section{HASIL PENELITIAN}

\subsection{Pemodelan Data Panel}

Untuk mengestimasi parameter model dengan data panel, terdapat beberapa model yang ditawarkan, yaitu: model common effect, model fixed effect, model random effect. ${ }^{21}$ Pengujian yang dilakukan untuk memilih model regresi yang terbaik adalah uji Chow, uji Hausman, dan uji Lagrange Multiplier.

Hasil uji Chow menunjukkan bahwa probabilitas cross-section $F$ dan cross-section chisquare adalah sebesar 0,0000. Angka ini lebih kecil dari tingkat signifikansi, yaitu sebesar 5\%. Kesimpulan yang diambil dari uji Chow ini adalah model fixed effect lebih baik daripada model common effect.

Hasil uji Hausman menunjukkan nilai probabilitas chi-square yang signifikan, yakni sebesar 0,0033. Angka ini lebih kecil dari tingkat signifikansi, yaitu 5\%. Oleh karena itu, kesimpulan dari uji Hausman adalah estimasi dengan menggunakan model fixed effect lebih baik daripada model random effect.

Berdasarkan hasil uji Chow dan uji Hausman, model data panel yang digunakan dalam penelitian ini adalah model fixed effect. Dalam penelitian ini, uji Lagrange Multiplier tidak digunakan karena uji

21 D. Nachrowi dan Hardius Usman, Pendekatan Populer dan Praktis Ekonometrika untuk Analisis Ekonomi dan Keuangan, (Jakarta: Lembaga Penerbit Fakultas Ekonomi Universitas Indonesia, 2006). 
Chow dan uji Hausman menunjukan model yang paling tepat adalah model fixed effect.

\subsection{Uji Asumsi Klasik}

Sebelum melakukan pengujian hipotesis dengan menggunakan analisis regresi linier berganda, dilakukan uji asumsi klasik pada model penelitian tersebut berupa uji normalitas, multikolinearitas, autokorelasi, dan heteroskedastisitas. Hasil pengujian menunjukkan variabel-variabel yang digunakan dalam penelitian telah memenuhi uji asumsi klasik.

\subsection{Uji Koefisien Determinasi}

Berdasarkan hasil analisis regresi sebagaimana dapat dilihat dalam Tabel 1, didapatkan nilai koefisien determinasi (Adjusted $R$ squared) sebesar 0,8229. Hal ini menunjukkan bahwa variasi variabel bebas yang digunakan mampu menjelaskan sebesar $82,29 \%$ variabel terikat. Sedangkan $17,71 \%$ dijelaskan oleh variabel lain yang belum disertakan dalam penelitian ini.

Tabel 1. Hasil Estimasi Regresi Linier Berganda Dependent Variable: TPT

\begin{tabular}{|c|c|c|c|c|c|}
\hline Variable & \multicolumn{2}{|c|}{ Coefficient } & Std. Error & t-Statistic & Prob. \\
\hline C & \multicolumn{2}{|c|}{10,26064} & 0,701775 & 14,62099 & 0,0000 \\
\hline PAD & \multicolumn{2}{|c|}{$-0,158431$} & 0,042972 & $-3,686860$ & 0,0006 \\
\hline DAU & \multicolumn{2}{|c|}{$-0,092572$} & 0,126267 & $-0,733147$ & 0,4674 \\
\hline DAK & \multicolumn{2}{|c|}{$-0,276168$} & 0,780624 & $-0,353779$ & 0,7252 \\
\hline DBH & \multicolumn{2}{|c|}{$-0,104129$} & 0,041258 & $-2,523845$ & 0,0154 \\
\hline BPG & \multicolumn{2}{|c|}{$-0,126326$} & 0,140289 & $-0,900472$ & 0,3729 \\
\hline BBJ & \multicolumn{2}{|c|}{0,097710} & 0,025742 & 3,795681 & 0,0005 \\
\hline $\operatorname{BMD}(-2)$ & \multicolumn{2}{|c|}{$-0,085363$} & 0,027899 & $-3,059663$ & 0,0038 \\
\hline \multirow{3}{*}{\multicolumn{2}{|c|}{$\begin{array}{l}\text { R-squared } \\
\text { Adjusted R-squared } \\
\text { Durbin-Watson stat }\end{array}$}} & & \multirow{3}{*}{\multicolumn{2}{|c|}{$\begin{array}{l}\text { F-statistic } \\
\text { Prob (F-statistic) }\end{array}$}} & 18,13405 \\
\hline & & 0,8 & & & 0,000000 \\
\hline & & 1,9 & & & \\
\hline
\end{tabular}

Sumber: Output Eviews 7.2

\subsection{Uji Hipotesis}

Berdasarkan analisis regresi linier berganda, diperoleh hasil uji hipotesis sebagai berikut:

1. Pengaruh kemandirian fiskal terhadap tingkat pengangguran

Pengujian atas hipotesis yang telah dirumuskan terkait pengaruh kemandirian fiskal daerah dapat dilihat melalui hasil uji $\mathrm{t}$ atas variabel PAD. Derajat kebebasan untuk menghitung $t$ tabel dihitung dengan formula $d f=n-k-1$ atau $60-7-1=52$. Dengan mengacu pada tabel titik persentase distribusi-t, maka nilai $t$-tabel dalam penelitian ini adalah 2,00665.

Berdasarkan hasil analisis regresi, nilai absolut t-hitung variabel PAD sebesar 3,686860. Angka ini lebih besar daripada nilai $t$-tabel penelitian ini. Selain itu, nilai probabilitas $t$-tabel variabel PAD lebih kecil daripada tingkat signifikansi. Dengan demikian dapat disimpulkan bahwa
PAD berpengaruh negatif dan signifikan terhadap TPT.

Hasil tersebut sesuai dengan hipotesis $\mathrm{H}_{\mathrm{a} 1}$ dan dapat dikatakan bahwa setiap seratus miliar Rupiah PAD yang dihasilkan akan menurunkan tingkat pengangguran sebesar 0,15\%. Hasil penelitian ini sejalan dengan penelitian Muda, et al. (2013). Pengaruh negatif PAD terhadap tingkat pengangguran menunjukkan bahwa pengelolaan PAD sudah diarahkan sesuai dengan fungsi alokasi APBD, yaitu untuk mengurangi pengangguran, sebagaimana yang diamanatkan oleh UU No. 33 Tahun 2004. Kemampuan pemerintah daerah mengelola PAD merupakan gambaran keberhasilan pemerintah daerah dalam meningkatkan kemandirian fiskal.

Peningkatan kemandirian fiskal yang dicapai oleh pemerintah daerah menandakan bahwa pelaksanaan desentralisasi fiskal telah berjalan dengan baik dan mampu mengatasi permasalahan sosial ekonomi masing-masing daerah, khususnya masalah pengangguran. Kemandirian fiskal merupakan cerminan dari keberhasilan daerah dalam menggali potensi sumber-sumber keuangan sendiri. Pengembangan potensi tersebut akan menciptakan PAD yang berguna untuk meningkatkan pelayanan publik.

Berdasarkan UU No. 33 Tahun 2004, PAD dapat digunakan untuk mendanai pelaksanaan otonomi daerah sesuai dengan potensi daerah. PAD digunakan untuk membiayai urusan pemerintahan agar sesuai dengan Standar Pelayanan Minimal. Pelayanan publik yang baik akan mendorong tumbuhnya kesejahteraan masyarakat dan memangkas birokrasi yang rumit seperti dalam hal pemberian izin mendirikan usaha. Hal ini akan meningkatkan ketertarikan investor untuk menanamkan modal di daerah, sehingga lapangan kerja dan kesempatan kerja akan meningkat, sedangkan tingkat pengangguran menurun.

2. Pengaruh penyaluran dana perimbangan terhadap tingkat pengangguran

Pengujian atas hipotesis yang telah dirumuskan terkait pengaruh penyaluran dana perimbangan dapat dilihat melalui hasil uji $t$ atas variabel DAU, DAK, dan DBH. Pengujian ini dilakukan untuk membuktikan hipotesis $\mathrm{H}_{\mathrm{a} 2}, \mathrm{H}_{\mathrm{a} 3}$, dan $\mathrm{H}_{\mathrm{a} 4}$.

Nilai absolut $t$-hitung atas variabel DAU adalah sebesar 0,733147 dan DAK sebesar 0,353779. Kedua nilai tersebut lebih kecil dari nilai $t$-tabel dan nilai probabilitas t-hitung kedua variabel tersebut lebih besar dari tingkat signifikansi yang telah ditetapkan, yaitu 5\%, sehingga dapat disimpulkan bahwa DAU dan DAK tidak 
mempunyai pengaruh signifikan terhadap TPT. Hasil ini tidak sesuai dengan hipotesis $\mathrm{H}_{\mathrm{a} 2}$ dan $\mathrm{H}_{\mathrm{a} 3}$.

Dengan mengacu pada hasil penelitian, DAU tidak memiliki pengaruh yang signifikan terhadap tingkat pengangguran. Padahal sejak tahun 2001, DAU merupakan instrumen utama dana perimbangan yang secara rutin disalurkan pemerintah pusat kepada pemerintah daerah dalam rangka pelaksanaan desentralisasi dengan nilai yang terus meningkat setiap tahun.

Tidak berpengaruhnya DAU terhadap tingkat pengangguran disebabkan karena 80 persen dari nilai DAU digunakan untuk belanja rutin. Selain itu, pada setiap penentuan DAU terdapat alokasi dasar, dimana alokasi dasar dihitung berdasarkan jumlah gaji Pegawai Negeri Sipil Daerah, sebagaimana yang dinyatakan pada Pasal 27 Ayat (2) UU No. 33 Tahun 2004.

Menurut laporan The Asia Foundation (2011), porsi belanja pegawai pada DAU yang digunakan untuk membayar gaji pegawai pemerintah daerah terus meningkat. Oleh karena itu, alokasi DAU yang digunakan untuk belanja pegawai tersebut tidak mampu memberikan pengaruh yang signifikan terhadap peningkatan kesejahteraan dan pemberdayaan masyarakat secara keseluruhan, khususnya untuk mengurangi pengangguran.

Penelitian yang dilakukan oleh Decentralization Support Facility (2010), Shah, et al. (2012) dan Tim Asistensi Desentralisasi Fiskal (2012) menyimpulkan bahwa pemerintah pusat perlu memperbaiki formula DAU yang digunakan saat ini dalam menentukan besaran DAU yang harus disalurkan oleh pemerintah pusat. Formulasi DAU yang digunakan saat ini dianggap masih lemah karena belum mampu memperbaiki kesenjangan fiskal antardaerah, sebagaimana tujuan dari penyaluran DAU sebagai equalization grant.

Hasil penelitian menunjukkan pula bahwa DAK tidak berpengaruh signifikan terhadap tingkat pengangguran. Hasil ini menunjukkan bahwa manfaat DAK dalam membiayai kebutuhan belanja pemerintah daerah guna menstimulus turunnya tingkat pengangguran masih belum optimal.

Salah satu penyebab belum optimalnya DAK dalam menurunkan tingkat pengangguran adalah karena pencairan DAK oleh pemerintah daerah lebih banyak dilakukan pada bulan Desember, sebagaimana yang dilaporkan oleh Decentralization Support Facility (2010). Pada periode Januari 2007-November 2007, penyaluran DAK baru mencapai 59,1\%, sedangkan pada tanggal 31 Desember 2007 penyaluran sudah mencapai 95\%. Hal ini menunjukkan bahwa dalam bulan Desember pencairan melonjak hingga 35,9\%. Hal ini juga terjadi untuk DAK Tahun Anggaran 2008 dan 2009, sebagaimana yang dinyatakan oleh Badan Pengawasan Keuangan dan Pembangunan (2011), bahwa penyerapan DAK secara besarbesaran terjadi di akhir tahun. Hal ini terlihat pula dari penyampaian Laporan Realisasi Penyerapan DAK yang terdiri atas Tahap I, II dan III yang dilakukan pada bulan November dan Desember.

Keterlambatan pencairan DAK dapat disebabkan karena keterlambatan pemerintah daerah dalam menetapkan peraturan daerah yang berkaitan dengan pencairan DAK. Birokrasi yang panjang dalam proses administrasi juga menghambat percepatan daya serap DAK yang akan digunakan untuk membiayai pengeluaran pemerintah daerah.

Keterlambatan pencairan DAK mengakibatkan penggunaan DAK untuk membiayai belanja pemerintah pada tahun yang bersangkutan belum maksimal, sehingga manfaat dari penyaluran DAK belum memiliki pengaruh yang signifikan terhadap penurunan tingkat pengangguran. Oleh karena itu, pemerintah daerah seharusnya mengatur pencairan DAK dengan lebih baik, sehingga DAK tersebut dapat segera digunakan untuk membiayai pengeluaran pemerintah dalam rangka meningkatkan pelayanan publik, khususnya untuk mengentaskan masalah pengangguran.

Nilai absolut t-hitung DBH sebesar 2,523845. Angka ini lebih besar daripada nilai t-tabel dan nilai probabilitasnya lebih kecil daripada tingkat signifikansi. Oleh karena itu, dapat disimpulkan bahwa DBH berpengaruh negatif dan signifikan terhadap TPT. Hasil ini sesuai dengan hipotesis $\mathrm{H}_{\mathrm{a} 4}$ dan dapat dikatakan bahwa setiap seratus miliar rupiah DBH yang diterima akan menurunkan tingkat pengangguran sebesar $0,1 \%$. Hasil penelitian ini mendukung penelitian Muda, et al. (2014), yang membuktikan pengaruh negatif dan signifikan dari DBH terhadap tingkat pengangguran.

DBH disalurkan kepada daerah berdasarkan angka persentase tertentu yang didasarkan atas daerah penghasil. DBH memiliki peran yang besar dalam mendorong dan mengurangi ketidakseimbangan vertikal antara pemerintah pusat dan daerah. Fungsi DBH sebagai block grant memberikan kewenangan penggunaan sepenuhnya kepada pemerintah daerah. Pemerintah daerah dapat menggunakannya untuk membiayai kegiatan pemerintah daerah sesuai dengan kebutuhan daerah, termasuk untuk mendorong pertumbuhan ekonomi 
daerah dan meningkatkan permintaan tenaga kerja.

Selain itu, hal lain yang mendukung hasil penelitian bahwa DBH berpengaruh signifikan terhadap tingkat pengangguran adalah adanya DBH Cukai Hasil Tembakau yang dialokasikan untuk mengurangi pengangguran. Hal itu diatur dalam Peraturan Menteri Keuangan No. 20 Tahun 2009 tentang Perubahan atas Peraturan Menteri Keuangan No. 84 Tahun 2008 tentang Penggunaan DBH Cukai Hasil Tembakau dan Sanksi atas Penyalahgunaan Alokasi DBH Cukai Hasil Tembakau. Provinsi di Wilayah Sumatera yang menerima DBH Cukai Hasil Tembakau adalah Aceh, Sumatera Utara, Sumatera Barat, Jambi, Sumatera Selatan, Lampung, dan Kepulauan Riau.

Latar belakang dari pemberian DBH tersebut adalah karena adanya beberapa regulasi yang dikeluarkan oleh pemerintah yang berdampak pada operasional industri tembakau, antara lain Peraturan Menteri Keuangan No. 200 Tahun 2008 tentang Tata Cara Pemberian, Pembekuan dan Pencabutan No. Pokok Pengusaha Barang Kena Cukai Untuk Pengusaha Pabrik dan Importir Hasil Tembakau. Peraturan tersebut mensyaratkan luas bangunan yang digunakan sebagai tempat untuk mendirikan usaha minimal seluas 200 meter persegi. Hal ini mengakibatkan penutupan tempat usaha dengan luas kurang dari yang disyaratkan tersebut, sehingga tenaga kerja pabrik tersebut harus kehilangan pekerjaan.

Oleh karena itu, untuk mengatasi peningkatan pengangguran tersebut pemerintah pusat menyalurkan insentif bagi pemerintah daerah berupa DBH Cukai Hasil Tembakau kepada pemerintah daerah. Penggunaan DBH Cukai Hasil Tembakau ini diarahkan untuk membiayai pengeluaran pemerintah dalam kegiatan pembinaan tenaga kerja yang terkena dampak penutupan usaha tembakau. Kegiatan pemerintah tersebut berupa pelatihan keterampilan kepada penganggur dan bantuan modal kerja, sehingga penganggur dapat memperoleh pekerjaan dan tingkat pengangguran akan menurun.

3. Pengaruh alokasi belanja daerah terhadap tingkat pengangguran

Pengujian atas hipotesis yang telah dirumuskan terkait pengaruh alokasi belanja pemerintah daerah terhadap tingkat pengangguran dapat dilihat melalui hasil $u j i-t$ atas variabel BPG, BBJ, dan BMD. Pengujian ini dilakukan untuk membuktikan hipotesis $\mathrm{H}_{\mathrm{a} 5}, \mathrm{H}_{\mathrm{a} 6}$, dan $\mathrm{H}_{\mathrm{a}}$.

Nilai absolut t-hitung atas variabel BPG adalah sebesar 0,900472. Nilai ini lebih kecil daripada nilai t-tabel dan nilai probabilitas t-tabel variabel tersebut lebih besar dari tingkat signifikansi, sehingga dapat disimpulkan bahwa belanja pegawai tidak berpengaruh signifikan terhadap TPT. Hasil ini tidak sesuai dengan hipotesis $\mathrm{H}_{\mathrm{a} 5}$ yang telah dirumuskan dan menunjukkan bahwa belanja pegawai belum mampu menstimulus turunnya tingkat pengangguran, meskipun anggaran belanja pegawai semakin meningkat setiap tahun dengan porsi yang cukup besar dalam anggaran pemerintah daerah.

Pengaruh belanja pegawai yang tidak signifikan terhadap tingkat pengangguran dikarenakan belanja pegawai lebih banyak dinikmati oleh pegawai negeri sipil daerah. Oleh karena itu, peningkatan belanja pegawai yang dikeluarkan oleh pemerintah daerah belum mampu meningkatkan kesejahteraan masyarakat secara keseluruhan.

Nilai absolut t-hitung atas variabel BBJ adalah sebesar 3,795681. Nilai ini lebih besar daripada nilai t-tabel dan nilai probabilitas $t$-tabel variabel tersebut lebih kecil dari tingkat signifikansi, sehingga dapat disimpulkan bahwa belanja barang dan jasa mempunyai pengaruh positif dan signifikan terhadap TPT, atau dapat dikatakan bahwa setiap seratus miliar Rupiah belanja barang dan jasa yang dikeluarkan, akan menaikkan tingkat pengangguran sebesar 0,09\%. Hasil ini tidak sesuai dengan hipotesis $\mathrm{H}_{\mathrm{a} 6}$ dan menunjukkan bahwa semakin besar belanja barang dan jasa, tingkat pengangguran terbuka semakin meningkat. Hasil penelitian ini mendukung penelitian Murwirapachena, et al. (2013) dan Akhmad, et al. (2013), yang membuktikan bahwa pengeluaran atas konsumsi barang dan jasa pemerintah terbukti berpengaruh positif dan signifikan terhadap pengangguran, serta merekomendasikan agar pemerintah mengurangi belanja barang dan jasa, dan menambah belanja modal yang terbukti lebih efektif dalam menurunkan tingkat pengangguran.

Kenaikan belanja barang dan jasa pemerintah daerah akan berdampak terhadap meningkatnya permintaan barang dan jasa. Friedman menyatakan bahwa peningkatan permintaan barang dan jasa menyebabkan kenaikan harga dan biaya faktor-faktor produksi, antara lain upah bagi tenaga kerja. ${ }^{22}$ Hal ini mengakibatkan peningkatan pengangguran karena perusahaan mengurangi

22 Milton Friedman, "The Role of Monetary Policy", The American Economic Review, 1968, Vol. 58, hlm. 1-17. 
tenaga kerja sebagai akibat dari kenaikan upah tersebut.

Berdasarkan uraian di atas, pemerintah daerah perlu mengurangi anggaran belanja barang dan jasa untuk mengurangi tingkat pengangguran. Penghematan yang dilakukan atas belanja barang dan jasa selanjutnya dapat dialokasikan untuk keperluan belanja modal.

Nilai absolut $t$-hitung atas variabel BMD sebesar 3,059663. Nilai ini lebih besar daripada nilai $t$ tabel. Selain itu, nilai probabilitas t-tabel variabel tersebut lebih kecil dari tingkat signifikansi yang digunakan dalam penelitian ini, yaitu sebesar 5\%, sehingga dapat disimpulkan bahwa belanja modal mempunyai pengaruh negatif dan signifikan terhadap TPT, atau dapat dikatakan bahwa setiap seratus miliar Rupiah belanja modal yang dikeluarkan, akan menurunkan tingkat pengangguran sebesar 0,08\%. Hasil ini sesuai dengan hipotesis $\mathrm{H}_{\mathrm{a}}$ dan menunjukkan bahwa belanja modal yang diperoleh mampu menstimulus turunnya tingkat pengangguran pada time lag dua tahun. Hasil penelitian ini mendukung penelitian Murwirapachena, et al. (2013) dan Akhmad, et al. (2013), yang menyebutkan bahwa belanja modal memiliki pengaruh yang negatif dan signifikan terhadap pengangguran dan merekomendasikan agar pemerintah meningkatkan belanja modal.

Penggunaan time lag dua tahun pada variabel belanja modal dalam penelitian ini menunjukkan bahwa belanja modal dalam menurunkan tingkat pengangguran diperlukan waktu dua tahun. Hal ini terjadi karena dalam upaya meningkatan kualitas hidup masyarakat dan kemajuan daerah melalui alokasi belanja modal, dibutuhkan waktu untuk proses pengadaan, pembangunan, penggunaan, pemanfaatan dan pada akhirnya berpengaruh terhadap tingkat pengangguran di Wilayah Sumatera.

Belanja modal yang dikeluarkan oleh pemerintah daerah ditujukan untuk pembangunan infrastruktur, sarana dan prasarana yang dibutuhkan di Wilayah Sumatera. Infrastruktur serta sarana dan prasarana yang baik akan meningkatkan ketertarikan investor untuk menanamkan modalnya. Peningkatan investasi Penanaman Modal Dalam Negeri (PMDN) di Wilayah Sumatera selama periode 2008 s.d. 2013 dapat dilihat pada Grafik 3.

\section{Grafik 3. Realisasi Investasi PMDN di Sumatera}

(dalam miliar Rupiah)

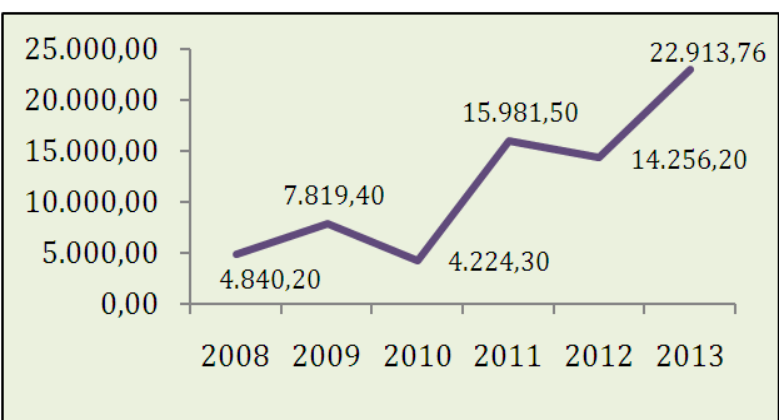

Sumber: Badan Koordinasi Penanaman Modal (2013)

Realisasi investasi PMDN di Wilayah Sumatera pada tahun 2013 mencapai 22.913,76 miliar Rupiah. Peningkatan investasi PMDN ini juga diikuti dengan peningkatan investasi Penanaman Modal Asing (PMA), sebagaimana dapat dilihat pada Grafik 4, yang pada tahun 2013 mencapai angka USD 3.395,3 juta.

\section{Grafik 4. Realisasi Investasi PMA di Sumatera}

(dalam juta USD)

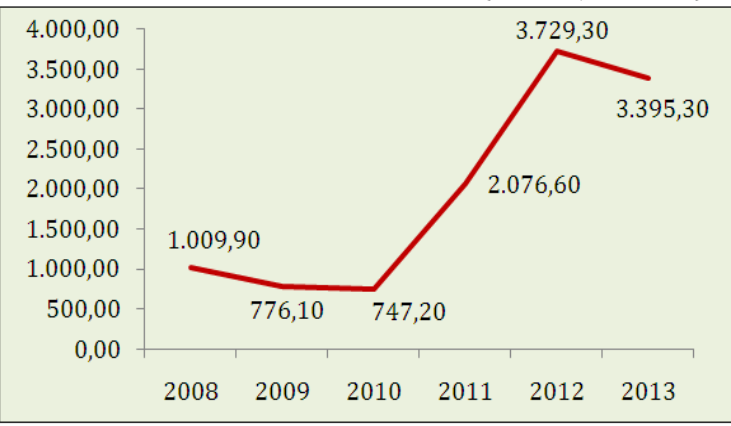

Sumber: Badan Koordinasi Penanaman Modal (2013)

Semakin banyak investor yang menanamkan modalnya di daerah maka jumlah lapangan kerja akan meningkat. Peningkatan lapangan pekerjaan akan memberi kesempatan kerja, sehingga tingkat pengangguran akan menurun. Berdasarkan uraian di atas, pemerintah daerah perlu meningkatkan alokasi belanja daerah untuk keperluan belanja modal.

\section{KESIMPULAN DAN SARAN}

Berdasarkan hasil analisis data yang telah dilakukan serta pembahasan yang telah diuraikan pada bab-bab sebelumnya, maka beberapa kesimpulan dari hasil penelitian ini sebagai berikut:

1. Pendapatan Asli Daerah (PAD) memiliki pengaruh negatif dan signifikan terhadap tingkat pengangguran. Hal ini menunjukkan bahwa penggunaan PAD oleh pemerintah 
daerah mendorong peningkatan pelayanan publik serta tumbuhnya kesejahteraan masyarakat. Peningkatan porsi PAD dalam pendapatan daerah sesuai dengan tujuan desentralisasi fiskal yaitu untuk meningkatkan kemandirian fiskal daerah.

2. Penyaluran dana perimbangan belum cukup efektif dalam mengatasi pengangguran. Secara parsial, DAU tidak memiliki pengaruh yang signifikan terhadap tingkat pengangguran. Hal ini dikarenakan sebagian besar DAU digunakan untuk belanja rutin dan membayar gaji pegawai negeri sipil daerah. Hasil penelitian juga menunjukkan bahwa DAK tidak memiliki pengaruh yang signifikan terhadap tingkat pengangguran. Hal ini dikarenakan terjadinya keterlambatan pencairan DAK dan lonjakan pencairan DAK yang terfokus di akhir tahun, sehingga DAK tidak dapat segera digunakan oleh pemerintah daerah untuk membiayai pengeluaran pemerintah. Dana Bagi Hasil (DBH) memiliki pengaruh yang negatif dan signifikan terhadap tingkat pengangguran. Adanya pemberian DBH Cukai Hasil Tembakau bertujuan untuk mengurangi pengangguran.

3. Hasil penelitian menunjukkan pula bahwa alokasi belanja daerah belum sepenuhnya diarahkan untuk mengatasi pengangguran. Peningkatan belanja pegawai tidak memiliki pengaruh yang signifikan terhadap tingkat pengangguran karena belanja pegawai lebih banyak dinikmati oleh pegawai negeri sipil daerah, bukan rakyat secara langsung. Selain itu, peningkatan belanja pegawai berdampak pada berkurangnya alokasi belanja modal yang terbukti lebih efektif dalam mengurangi tingkat pengangguran. Hasil penelitian juga menunjukkan bahwa belanja barang dan jasa memiliki pengaruh yang positif dan signifikan terhadap tingkat pengangguran. Kenaikan belanja barang dan jasa pemerintah berdampak terhadap kenaikan harga dan biaya faktorfaktor produksi, antara lain upah tenaga kerja. Hal ini mengakibatkan peningkatan pengangguran karena perusahaan mengurangi tenaga kerja terkait peningkatan upah tersebut. Belanja modal memiliki pengaruh negatif dan signifikan terhadap tingkat pengangguran. Infrastruktur yang baik akan meningkatkan ketertarikan investor untuk menanamkan modalnya sehingga lapangan kerja meningkat dan pengangguran menurun.

Berdasarkan kesimpulan di atas, saran yang dapat diberikan adalah sebagai berikut:

1. Pemerintah pusat sebaiknya mempertimbangkan perbaikan formulasi DAU bagi pemerintah daerah agar dana yang disalurkan dapat lebih berguna untuk meningkatkan kesejahteraan masyarakat secara keseluruhan.

2. Pemerintah daerah harus mengatur pencairan DAK dengan lebih baik agar tidak terjadi penumpukan di akhir tahun dan dana yang telah disiapkan oleh pemerintah pusat dapat segera digunakan.

3. Pemerintah daerah perlu meningkatkan pengeluaran untuk belanja modal dan mengurangi belanja barang dan jasa untuk mengurangi tingkat pengangguran.

\section{IMPLIKASI DAN KETERBATASAN}

\subsection{Implikasi}

Implikasi kebijakan yang dapat disimpulkan berdasarkan hasil pembahasan dan simpulan yang diuraikan di atas adalah sebagai berikut:

1. Pemerintah pusat sebaiknya mempertimbangkan perbaikan formulasi DAU dengan menghilangkan alokasi dasar yang digunakan untuk belanja pegawai, agar DAU dapat dialokasikan untuk belanja lain yang lebih berguna untuk meningkatkan kesejahteraan masyarakat secara keseluruhan.

2. Pemerintah daerah harus mengatur pencairan DAK dengan lebih baik agar tidak terjadi penumpukan di akhir tahun dan dana yang telah disiapkan oleh pemerintah pusat dapat segera digunakan.

3. Pemerintah daerah perlu meningkatkan pengeluaran untuk belanja modal dan mengurangi belanja barang dan jasa untuk mengurangi tingkat pengangguran.

\subsection{Keterbatasan}

Dalam penelitian ini terdapat beberapa keterbatasan yang menyebabkan hasil penelitian kurang optimal. Keterbatasan tersebut antara lain:

1. Penelitian ini belum menyertakan variabel bebas sumber pendanaan APBD lainnya seperti pinjaman daerah dan belanja daerah lainnya seperti belanja bantuan dan subsidi.

2. Objek penelitian yang digunakan untuk penelitian hanya mencakup provinsi-provinsi di Wilayah Sumatera. Penelitian selanjutnya sebaiknya menambah variabel yang diperkirakan dapat mempengaruhi tingkat pengangguran dan mengangkat objek penelitian wilayah-wilayah lain di Indonesia. 


\section{DAFTAR PUSTAKA (REFERENCES)}

Akhmad, et al. (2013). "The Impact of Fiscal Policy on the Regional Economy: Evidence from South Sulawesi, Indonesia", Journal of Applied Sciences Research, Vol. 45, 24632474.

Badan Pengawasan Keuangan dan Pembangunan. (2011). Pedoman Monitoring Dana Alokasi Khusus, Dana Penguatan Desentralisasi Fiskal dan Percepatan Pembangunan Daerah, Dana Penguatan Infrastruktur dan Prasarana Daerah, serta Dana Percepatan Pembangunan Infrastruktur Pendidikan Tahun Anggaran 2010. Jakarta: BPKP.

Badan Pusat Statistik. (2011). Pertumbuhan dan Persebaran Penduduk Indonesia: Hasil Sensus Penduduk 2010. Jakarta: BPS.

Badan Pusat Statistik. (2013). Keadaan Angkatan Kerja di Indonesia Agustus 2013. Jakarta: BPS.

Decentralization Support Facility. (2010). Laporan Penelitian Dana Transfer Pusat ke Daerah. Jakarta: World Bank.

Friedman, Milton. (1968). The Role of Monetary Policy. The American Economic Review, Vol. 58, hlm. 1-17.

Ghozali, Imam. (2005). Aplikasi Analisis Multivariate dengan Program SPSS. Semarang: Badan Penerbit Universitas Diponegoro.

Gujarati, Damodar. (2006). Basic Econometrics. Edisi ke-4. New York: The McGraw-Hill Companies.

Lewis, W. Arthur. (1954). Economic Development with Unlimited Surplus of Labour. The Manchester School, Vol. 22, hlm. 139-191.

Mahdavi, Saeid dan Emmanuel Alanis. (2013). Public Expenditures and The Unemployment Rate in American States: Panel Evidence. Applied Economics, Vol. 45, hlm. 2926-2937.

Muda, Iskandar, et al. (2014). "The Effect of Fiscal Potential, Fiscal Needs and Internal Control on the Provincial Intergovernmental Transfer Allocation in the Districts/Cities in North Sumatera, Indonesia". International Journal of Management Sciences and Business Research, Vol. 3, hlm. 22-35.

Mulyana, Budi, Subkhan, dan Kuwat Slamet. (2006). Keuangan Daerah: Perspektif Desentralisasi Fiskal dan Pengelolaan APBD di Indonesia. Jakarta: LPKPAP.

Murwirapachena, Genius, et al. (2013). "Fiscal Policy and Unemployment in South Africa:
From 1980 to 2010". Mediterranean Journal of Social Sciences, Vol. 4, hlm. 579-587.

Nachrowi, D. Nachrowi dan Hardius Usman. (2006). Pendekatan Populer dan Praktis Ekonometrika Untuk Analisis Ekonomi dan Keuangan. Jakarta: Lembaga Penerbit Fakultas Ekonomi Universitas Indonesia.

Nugroho, Bhuono Agung. (2005). Strategi Jitu Memilih Metode Statistik Penelitian Dengan SPSS. Yogyakarta: ANDI.

Peraturan Pemerintah No. 55 Tahun 2005 tentang Dana Perimbangan.

Peraturan Pemerintah No. 58 Tahun 2005 tentang Pengelolaan Keuangan Daerah.

Peraturan Menteri Keuangan No. 180 Tahun 2013 tentang Pedoman Umum dan Alokasi Dana Alokasi Khusus Tahun Anggaran 2014.

Peraturan Menteri Keuangan No. 20 Tahun 2009 tentang Perubahan atas Peraturan Menteri Keuangan No. 84 Tahun 2008 tentang Penggunaan DBH Cukai Hasil Tembakau dan Sanksi atas Penyalahgunaan Alokasi DBH Cukai Hasil Tembakau.

Ranis, Gustav dan John C. H. Fei. (1961). "A Theory of Economic Development". The American Economic Review, Vol. 51, hlm. 533-565.

Shah, Anwar, et al. (2012). General Purpose CentralProvincial-Local Transfers (DAU) in Indonesia, From Gap Filling to Ensuring Fair Access to Essential Public Services. Jakarta: World Bank.

Sukirno, Sadono. (2000). Makroekonomi Modern. Jakarta: PT. Raja Grafindo.

Sumarsono, Hadi dan Sugeng H. Utomo. (2009). "Deliberate Inflation Pada Kebijakan Desentralisasi Fiskal Jawa Timur dan Dampak Bagi Pertumbuhan Daerah". Jurnal Ekonomi Studi Pembangunan, Vol. 3, hlm. 157-168.

The Asia Foundation. (2011). Local Economic Governance. Jakarta: Asia Foundation.

Tiebout, Charles M. (1956). "A Pure Theory of Local Expenditures". Journal of Political Economy, Vol. 64, hlm. 416-424.

Tim Asistensi Desentralisasi Fiskal. (2012). "Reformulasi DAU Untuk Memperkuat Peran Sebagai Equalization Grant". Laporan Penelitian Dana Transfer Pusat ke Daerah. Jakarta: World Bank.

Undang-Undang No. 17 Tahun 2003 tentang Keuangan Negara.

Undang-Undang No. 32 Tahun 2004 tentang Pemerintahan Daerah. 
Undang-Undang No. 33 Tahun 2004 tentang Perimbangan Keuangan antara Pemerintah Pusat dan Pemerintahan Daerah. 